\title{
CONSTRUCTED WETLANDS A COMPREHENSIVE REVIEW
}

\author{
Luna Al Hadidi ${ }^{* 1} \bowtie$ \\ ${ }^{1}$ Directorate of Water and Soil Researches, National Agricultural Research Center, P.O. Box 639, Baq'a 19381, \\ Amman, Jordan.
}

Received 5 August 2021
Accepted 16 August 2021
Published 31 August 2021

\section{CorrespondingAuthor}

Luna Al Hadidi, luna.hadidi@narc.gov.jo DOI

10.29121/granthaalayah.v9.i8.2021. 4176

Funding: This research received no specific grant from any funding agency in the public, commercial, or not-for-profit sectors.

Copyright: (C) 2021 The Author(s). This is an open access article distributed under the terms of the Creative Commons Attribution License, which permits unrestricted use, distribution, and reproduction in any medium, provided the original author and source are credited.

\section{ABSTRACT}

Constructed wetlands are wastewater treatment systems consisted of one or more treatment cells in a building designed and constructed to provide wastewater treatment. Constructed wetlands are classified into two types: free water surface (FWS) wetlands (also known as surface flow wetlands) closely resemble natural wetlands in appearance because they contain aquatic plants that are rooted in a soil layer on the bottom of the wetland and water flows through the leaves and stems of plants. Subsurface flow wetlands (SSF) or known as a vegetated submerged bed (VSB) systems do not resemble natural wetlands because they have no standing water. They contain a bed of media (such as crushed rock, small stones, gravel, sand, or soil) that has been planted with aquatic plants. When properly designed and operated, wastewater stays beneath the surface of the media, flows in contact with the roots and rhizomes of the plants, and is not visible or available to wildlife. Constructed wetlands are an appropriate technology for areas where inexpensive land is generally available and skilled labor is less available. In this paper, a comprehensive review covered types, characteristics, design variation and considerations, limitations, and the advantages and disadvantages of constructed wetlands.

Keywords: Constructed Wetlands, Wastewater Treatment, Ecology, Environmental Protection

\section{INTRODUCTION}

Water quality deterioration created pressure on decision-makers to adopt stringent regulations to find new means of cost-efficient water treatment methods in order to create healthy ecological conditions Forslund et al. (2009). Constructed wetlands are a natural and cost-efficient treatment process to enhance and improve water quality Jing et al. (2001) and decrease overall eutrophication Greenaway (2001), Sirianuntapiboon and S. Jitvimolnimit (2007). Constructed wetlands being in use since the '50s and provide better treatment for different kinds of wastewater such as (urban runoff, municipal wastewater, industrial wastewater, agricultural waste, and acid mine drainage by mimic biological, physical, and chemical processes that happen in natural wetland systems Vymazal (2011). The use of constructed wetlands for wastewater treatment has drastically increased over the last 40 years Bastian and Hammer, (2020), Vymazal (2011). Constructed wetlands are considered as an "ecofriendly" system to replace conventional secondary and tertiary municipal and industrial wastewater treatment processes Dhote and Dixit (2009), Moreira and Dias (2020). Constructed wetlands are fast gaining ground and became a 
practical water resource management strategy in many developing countries Yalcuk and Ugurlu (2009)

Constructed wetlands for wastewater treatment substituted conventional wastewater treatment processes and targets to create a sustainable and robust treatment system based on a complex natural ecosystem Bastian and Hammer, (2020). Wetland as an unconventional treatment technology for wastewater has great potential in developing countries which provides a comparative advantage over conventional, mechanized treatment processes. it has a high level of selfsufficiency, provides an ecological balance, and is economically feasible Galbraith et al. (2005).

Usually, constructed wetland well known consist designed basin that comprises water, substrate material, and vascular plants. These components can be deployed in constructing a wetland Vymazal (2010). additionally, wetlands contain microbial communities and aquatic invertebrates which can grow naturally Vymazal (2010) . The flow in constructed wetlands is controlled and the water spreads consistently among the wetland plants. Constructed wetlands mimic the optimal treatment conditions which could be found in natural wetlands, with supreme flexibility of being constructible at almost any location and different conditions Vymazal (2007), Batool and Saleh (2020). Constructed wetlands with developing macrophytes are well known used to treat municipal wastewater, representing a tertiary treatment stage Vymazal (2011). In the constructed wetland, wastewater either flow on top of the existing soil (surface wetland) or through a porous medium such as gravel (subsurface wetland). Different mechanisms were suggested to improve water quality in constructed wetlands systems and they are frequently interrelated. These mechanisms include Vymazal (2001):

1) Settling of suspended particular matter PM.

2) Filtration and chemical precipitation through contact of wastewater with substrate litter and plants.

3) Chemical transformation of pollutants.

4) Adsorption and ion exchange on the surfaces of plants, substrate, sediment, and litter.

5) Breakdown and transformation of pollutants by microorganisms

6) Plants uptake of nutrients and

7) Plants predation and natural die-off of pathogens.

The growing interest in wetland systems is due in part to the recognition that natural systems offer. Due to the excessive advantages that wetlands and constructed wetlands can provide over conventional activated sludge or trickling filter systems the growing interest in wetlands became prominent. wetlands often consume less energy, are more reliable, require less operation and maintenance and, as a result, costs less and had an added ecosystem value Vymazal (2010).

\section{CONSTRUCTED WETLANDS CHARACTERISTICS 2.1. SUBSTRATES}

Wetland substrates physically are the support the wetland vegetation, which offer sites where biochemical and chemical transformations processes occur, and provide sites for storage of removed pollutants and waste. Usually, substrates include soil type, sand, gravel, and organic materials Yang et al. (2018). Most soils are suitable for constructed wetlands Scholz and Lee (2005). But for design considerations, different soil properties should be considered in selecting soils to comprise cation exchange capacity (CEC), soil pH, electrical conductivity (EC), soil 
texture, and soil organic matter. It is recommended to have a constructed substrate of sand or gravel when the receiving domestic and agricultural wastewaters are highly loaded with nutrients, such as can be built with. It was reported that soils that contain more than $15 \%$ clay are generally suitable for constructed wetland substrate Vymazal (2010). Also, gravel and sands are highly suitable for constructed wetlands substrate and are considered inexpensive materials and provide an ideal texture for hand planting. Moreover, organic material found in the substrate provides a source of carbon to support microbial activity. Organic material also consumes oxygen and creates anoxic environments that are required for some treatment processes Vymazal (2001), Scholz and Lee (2005).

\subsection{HYDROLOGIC CHARACTERISTICS}

Periods of inundation and saturation created in the wetlands are due to the hydrologic regime of the wetlands. Hydrologic conditions affect the soils and nutrients conditions and characteristics, which in turn influence the status of the biota Vymazal (2001). The flow and storage volume determine the length of time that water spends in the wetland and, thus, the opportunity for interactions between waterborne substances and the wetland ecosystem Vymazal (2001), Scholz and Lee (2005). hydrological characteristics of wetlands include retention time, water depth, flow velocity through the wetland, and the number of days per year in which the wetland is inundated is among the most important aspects of the wetlands Vymazal (2001).

\subsection{WETLAND VEGETATION}

Wetlands are typically a suitable home to a variety of microbial and plant species due to the presence of ample water Brix (1994). The presence of macrophytes is one of the most obvious features of wetlands and it distinguishes constructed wetlands from unplanted soil filters or lagoons. Wetlands are home to a diverse group of plants, including emergent, floating, and submerged species Vymazal (2001). emergent macrophytes occurrence and distribution are easily managed and they are specified for wastewater treatment wetlands Fonder and Headley (2013). The main role of wetland vegetation is to assimilate nutrients into plant biomass and oxygenates the substrate in the vicinity of the plant root Brix (1994). Macrophytes remove pollutants by directly assimilating them into their tissue and providing surfaces and a suitable environment for microorganisms to transform the nutrients and decrease their concentrations Healy et al. (2007). The macrophytes growing in constructed wetlands have several properties in relation to the treatment process (Table 1) that make them an essential component of the design.

Table 1 Role of Macrophytes in Constructed Wetlands treatment system, adapted from Brix (1997), Brix (2003).

\begin{tabular}{|c|c|}
\hline Macrophyte Property & Role in Treatment Process \\
\hline \multirow[t]{5}{*}{ Aerial plant tissue } & Light attenuation $\rightarrow$ reduced growth of phytoplankton \\
\hline & Influence of microclimate $\rightarrow$ insulation during winter \\
\hline & Reduced wind velocity $\rightarrow$ reduced risk of re-suspension \\
\hline & Aesthetic pleasing appearance of the system \\
\hline & Storage of nutrients. \\
\hline
\end{tabular}


Reduced current velocity $\rightarrow$ increased rate of sedimentation, reduced risk of re-suspension

Provides surface area for attached biofilms

Excretion of photosynthetic oxygen $\rightarrow$ increases aerobic degradation Uptake of nutrients.

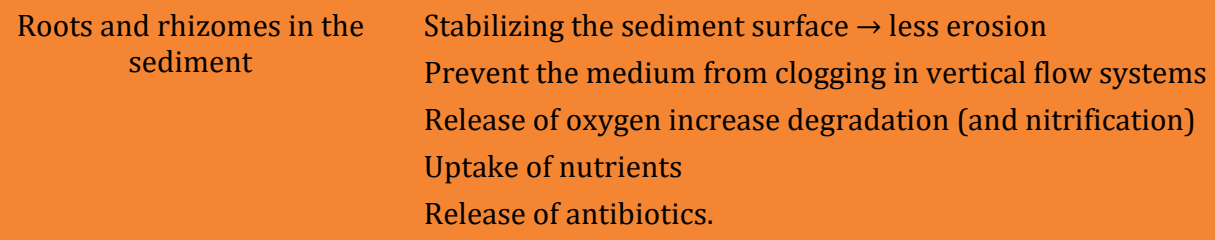

Source (Brix (1997), Brix (2003))

Persistent emergent plants are the most often used in constructed wetlands, such as bulrushes (Scirpus), spikerush (Efeocharis), other sedges (Cyperus), Rushes (Juncus), common reed (Phragrnites), and cattails (Typha) (Table 2). Not all wetland species are suitable for wastewater treatment since plants for treatment wetlands must be able to tolerate the combination of continuous flooding and exposure to wastewater or stormwater containing relatively high and often variable concentrations of pollutants Vymazal (2013), Kadlec and Wallace (2008). Wetland plants are adapted to survive in saturated conditions Pezeshki (2001). While most plants absorb oxygen through their roots, wetland plants can also absorb oxygen through their stems and leaves and transport it to their roots through specialized root cells Pezeshki (2001).

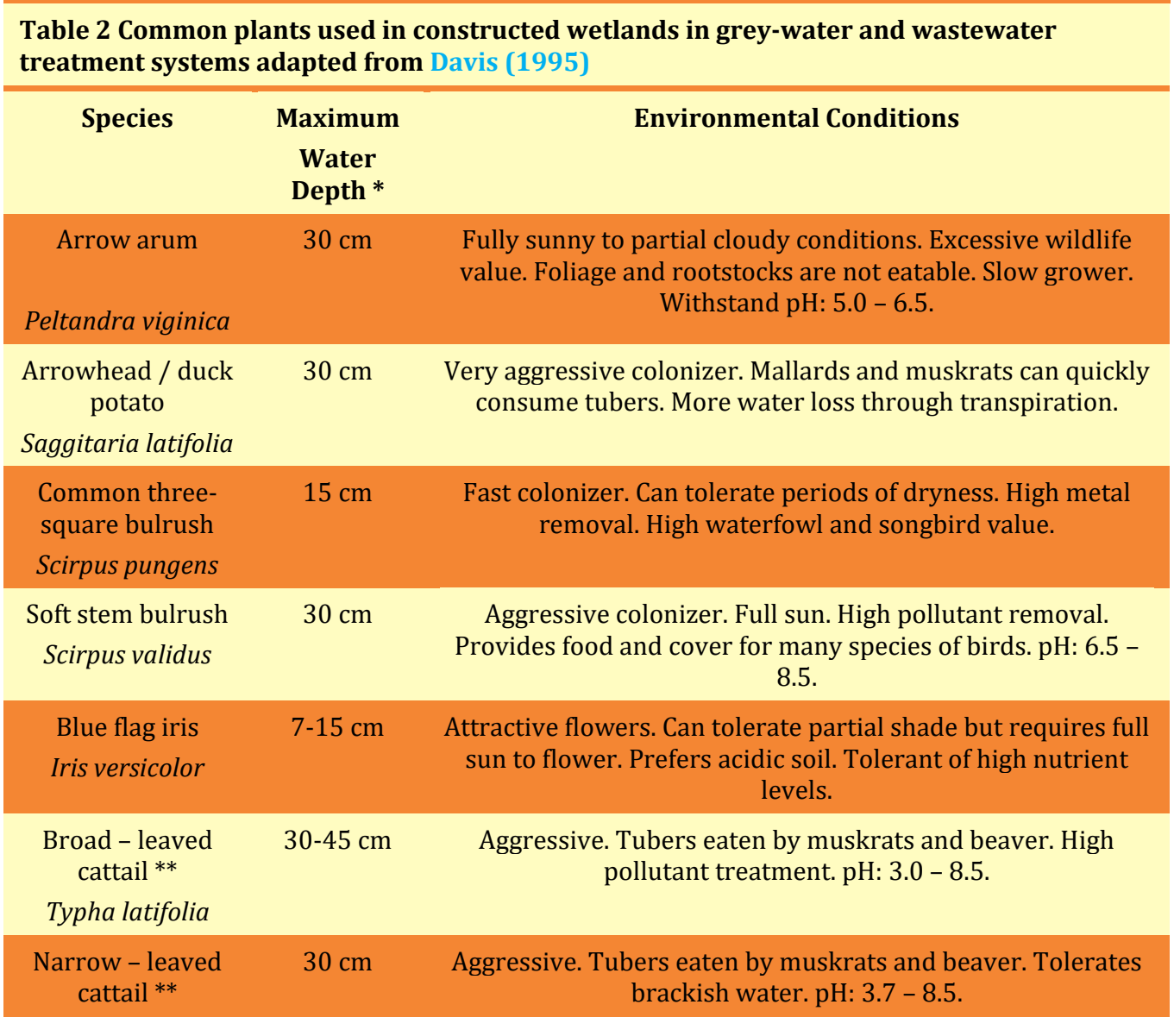




\begin{tabular}{|c|c|c|}
\hline $\begin{array}{l}\text { Reed canary grass } \\
\text { Phalaris } \\
\text { arundinocea }\end{array}$ & $15 \mathrm{~cm}$ & $\begin{array}{c}\text { Grows on exposed areas and in shallow water. Good ground } \\
\text { cover for berms. }\end{array}$ \\
\hline $\begin{array}{l}\text { Lizard's tail } \\
\text { Saururus cernuus }\end{array}$ & $15 \mathrm{~cm}$ & $\begin{array}{l}\text { Rapid grower. Shade tolerant. Low wildlife value except for } \\
\text { wood ducks. }\end{array}$ \\
\hline $\begin{array}{l}\text { Pickerelweed } \\
\text { Pontedaria } \\
\text { cordata }\end{array}$ & $30 \mathrm{~cm}$ & $\begin{array}{l}\text { Full sun to partial shade. Moderate wildlife value. Nectar for } \\
\text { butterflies. pH: } 6.0-8.0 \text {. }\end{array}$ \\
\hline $\begin{array}{l}\text { Common reed } \\
\text { Phragmites } \\
\text { australis }\end{array}$ & $7 \mathrm{~cm}$ & $\begin{array}{l}\text { Highly invasive; considered a pest species in many places. } \\
\text { Poor wildlife value. } \mathrm{pH}: 3.7-8.0 \text {. }\end{array}$ \\
\hline $\begin{array}{l}\text { Soft rush } \\
\text { Juncus effuses }\end{array}$ & $7 \mathrm{~cm}$ & $\begin{array}{l}\text { Tolerate wet or dry conditions. Food for birds. Often grows in } \\
\text { tussocks or hummocks. }\end{array}$ \\
\hline $\begin{array}{l}\text { Spike rush } \\
\text { Eleocharis } \\
\text { palustris }\end{array}$ & $7 \mathrm{~cm}$ & Tolerate partial shade. \\
\hline $\begin{array}{l}\text { Sedges } \\
\text { Carex spp. }\end{array}$ & $7 \mathrm{~cm}$ & $\begin{array}{l}\text { Many wetlands and several upland species. High wildlife } \\
\text { value for waterfowl and songbirds. }\end{array}$ \\
\hline $\begin{array}{l}\text { Spatterdock } \\
\text { Nuphar luteum }\end{array}$ & $\begin{array}{l}150 \mathrm{~cm} \\
60 \mathrm{~cm}\end{array}$ & $\begin{array}{l}\text { Tolerant of fluctuating water levels. Moderate food values for } \\
\text { wildlife, high cover value. Tolerate acidic water (up to } \mathrm{pH} \\
\text { 5.0). }\end{array}$ \\
\hline $\begin{array}{l}\text { Sweet flag } \\
\text { Acorus calamus }\end{array}$ & $7 \mathrm{~cm}$ & $\begin{array}{l}\text { Produces distinctive flowers. Not a rapid colonizer. Tolerates } \\
\text { acidic conditions. Tolerate of dry periods and partial shade. } \\
\text { Low wildlife value. }\end{array}$ \\
\hline $\begin{array}{l}\text { Wild rice } \\
\text { Zizania aquattica }\end{array}$ & $30 \mathrm{~cm}$ & $\begin{array}{l}\text { Requires full sun. High wildlife value (seeds, plant parts, and } \\
\text { rootstocks are food for birds). Eaten by muskrats. Annual, } \\
\text { non-persistent. Does not reproduce vegetatively. }\end{array}$ \\
\hline
\end{tabular}

It is recommended that native and local species should be used for wastewater and storm-water constructed wetlands, because they are adapted to the local climate conditions, soils, and surrounding plant and animal communities, and have efficient treatment ability Vymazal (2013), Tanner (1996). Several studies measuring both types of treatment systems, with and without plants, proved that the performance of constructed wetlands is better in the presence of (Kadlec and Knight, 1996) Kadlec and Wallace (2008), Tanner (1996). Major nutrients (N, P, and K) consist on average of 2.26, 0.25 , and $2.6 \%$ dry weight of plant biomass typically used in wetland treatment systems. Studies showed that wetland vegetation can directly uptake and remove up to $20 \%$ of nutrients found within treatment effluent depending on the type of vegetation and climatic conditions. The uptake capacity of emergent macrophytes is 50 to $150 \mathrm{~kg}$ P ha- 1 year- 1 and 1000 to $25000 \mathrm{~kg} \mathrm{~N}$ ha-1 year-1 Vymazal (2011), Vymazal (2007), Vymazal (2001), LaFlamme (2006). However, the removal of nutrients through direct uptake by plants is only significant in the short term Vymazal (2007).

\subsection{WETLAND MICROORGANISMS AND ANIMALS}

Microorganisms that exist in wetlands include a diverse microflora of bacteria, fungi, and algae that are essential for nutrients cycling and pollutant transformations and removal Kadlec and Wallace (2008). Wetland microorganisms have the ability to remove soluble organic matters, coagulate and colloidal particles, 
stabilize organic matter, and uses organic matter and convert it into gases and new cell tissue Stottmeister et al. (2003). Microbial transformations that occur in wetlands are aerobic and anaerobic; microorganisms are the same as in the conventional wastewater treatment processes Juhanson and Truu (2009). Different types of organisms, however, have specific tolerances and requirements for dissolved oxygen, temperature ranges, and nutrients. Constructed wetlands provide enriched habitats for diverse invertebrates and vertebrates. Invertebrate animals, such as insects and worms have a special role in the treatment process by fragmenting detritus, consuming organic matter, and act as important predators of mosquito larvae, they are also attracting a variety of amphibians, birds, turtles, and mammals Kadlec and Wallace (2008), Juhanson and Truu (2009).

\section{CONSTRUCTED WETLANDS TYPES}

Constructed wetlands are classified into various parameters. The most significant parameters are a water flow regime (surface and sub-surface) and the type of macrophytic growth (as emergent, submerged, free-floating, and floatingleaved plants) Vymazal (2010), Vymazal (2001). The quality of the final effluent from the systems improves with the complexity and the improvement of the system Vymazal and Kröpfelová (2008). Two general types of wetlands that are typically constructed for wastewater treatment are free water surface flow (FWS) and subsurface flow (SSF) wetlands Vymazal (2001).

\subsection{FREE WATER SURFACE FLOW WETLANDS}

A free water surface (FWS) wetland is designed to comprise a shallow basin, soil, or another medium to support the roots of vegetation, and a water control structure that maintains a shallow depth of water Vymazal (2001), Kadlec and Wallace (2008), Davis (1995). Plug-flow conditions are achieved in FWS by maintaining shallow water depth, low water flows velocity, and the presence of the plant stalks and litter to regulate water flow and, especially in long and narrow channels. Surface-flow constructed wetlands simulate natural wetlands where water is introduced above the ground surface and flows through the wetlands at depths averaging less than $15 \mathrm{~cm}$, ranging up to $30 \mathrm{~cm}$ (Figure 1) Kadlec and Wallace (2008). FWS wetlands can offer wildlife habitat and aesthetic benefits as well as a perfect water treatment process. In FWS wetlands, aerobic conditions are dominant near the surface layer while the deeper layers and waters and substrate are usually contained an anaerobic regime Vymazal (2011), Vymazal (2001), Kadlec and Wallace (2008). In many systems, removal efficiency is affected by the proportional relation of the inflow of concentrations. While in FWS constructed wetlands have an effluent with low concentrations of organics and suspended solids which reflect better removal. It was reported that the removal efficiency of nitrogen and phosphorus is highly variable and reaches 50\% Vymazal and Kröpfelová (2008), Vymazal and Kröpfelová (2009). Also, the removal efficiency of fecal coliforms varies and could be between one and two folds Vymazal (2007), Vymazal and Kröpfelová (2008), Vymazal and Kröpfelová (2009). A potential layout would be a cell with an open water zone for initial solids settling to promote solids flocculation and separation, then an emergent vegetation zone with two days retention at maximum flow, then an open water zone of two days retention, and then an emergent vegetation zone of two days retention. FWS-constructed wetlands have been designed with an aspect ratio, (which is length: width ratio) of less than 1:1 to over 90:1 Scholz and Lee (2005), Kadlec and Wallace (2008), Davis (1995), but most recommended and optimum ratios were found to be in the range of 3:1 to 5:1. 
Approximately $15 \mathrm{~cm}$ of soil layer was placed over the liner to support vegetation Kadlec and Wallace (2008). Wetland plants can be established either by seeding or transplanting. Maintenance of an FWS wetland may is cheap and easy, it includes periodic burning of the vegetation in the treatment wetland, monitoring and adjusting the water surface elevation, keeping the inlet and outlet structures of the wetlands clear of debris be screening, and sediment removal when necessary Bendoricchio et al. (2000)

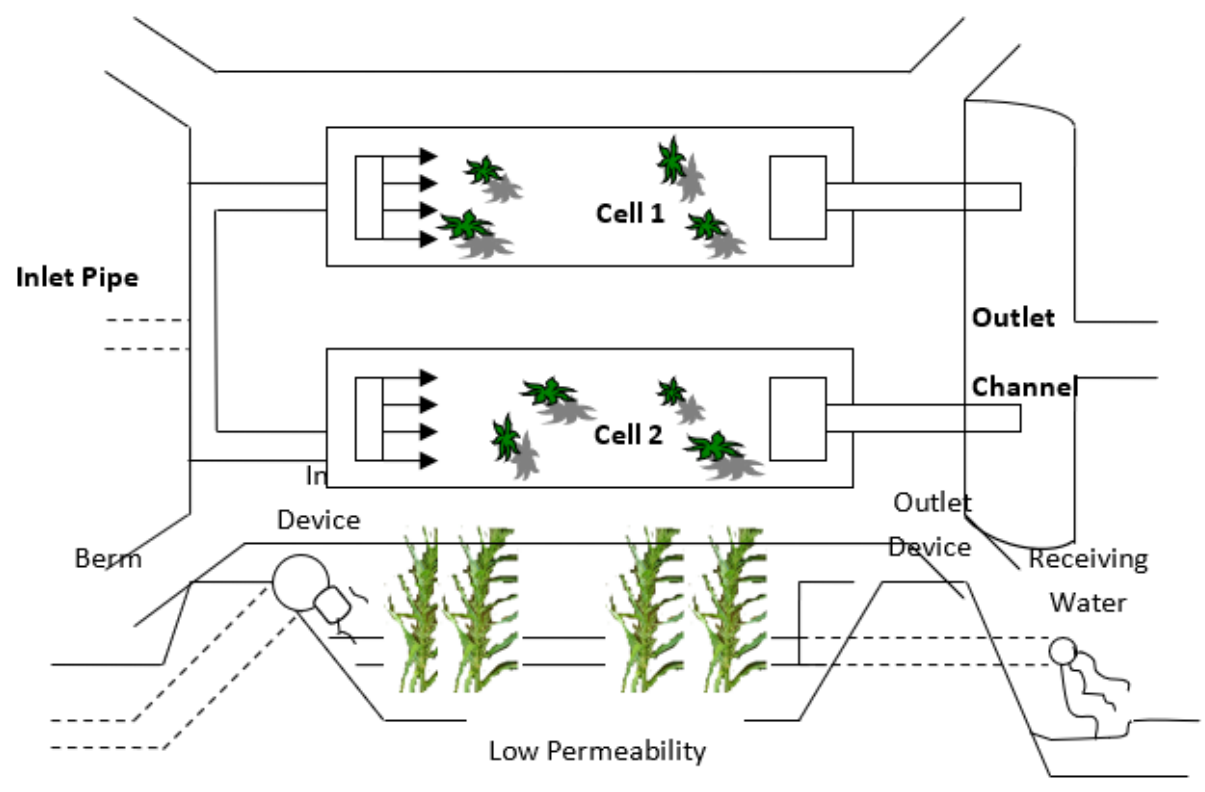

Figure 1 Plan and Profile of a Typical Free Water Surface Wetland

\subsection{SUBSURFACE FLOW WETLANDS}

The first subsurface flow pilot-scale wetland was designed in the 50's 1950s in Germany by Käthe Seidel Vymazal (2010). Constructed wetlands with the subsurface flow may are classified according to the direction of the water flow either horizontal HF or vertical flow VF Vymazal and Kröpfelová (2008). A subsurface flow (SSF) wetland comprises a sealed basin with a porous substrate of rock or gravel, vegetation, and the outlet control system Vymazal (2011), Vymazal (2010), Kadlec and Wallace (2008), Davis (1995). SSF wetlands may contain up to $4120 \mathrm{~cm}$ of gravel, and the water surface level is kept below the top surface of the gravel Kadlec and Wallace (2008). The flow path in SFF constructed wetlands is horizontal, while in some systems vertical flow paths could be found (Figure 2) Vymazal (2010). Generally, in SSF wetland seedlings must be planted since the gravel substrate is often not suitable and favorable to seed germination and establishment Kadlec and Wallace (2008).Organic compounds are degraded aerobically as well as anaerobically by bacteria attached to the plant's underground organs (i.e., roots and rhizomes) and media surface mimicking trickling surfaces as in the conventional biological treatment process Vymazal (2010), Scholz and Lee (2005). However, oxygenation of the rhizosphere of HF constructed wetlands is insufficient and, therefore, incomplete nitrification is the major cause of limited nitrogen removal which in best could reach 50\% Vymazal and Kröpfelová (2008), Vymazal and Kröpfelová (2009). In SSF constructed wetlands volatilization, adsorption, and plant uptake play a negligible role in nitrogen removal Vymazal and Kröpfelová (2008). Phosphorus removal occurred by ligand exchange reactions, the summary 
of the mechanism is that could phosphate displaces water or hydroxyls group from the surface of Fe iron and (Al) aluminum hydrous oxides Jing et al. (2001), Vymazal (2007), Cui et al. (2015). Microbial pollution removal is mainly done by a combination of physical, chemical, and biological processes and factors Coban et al. (2015). Nonetheless, because of the variation in hydraulic gradient requirements, the aspect ratio (L: $\mathrm{W}$ ) it have been recommended to be relatively low and (in the range of $0.4: 1$ to $3: 1$ ) in order to provide the flexibility and the reserve capacity for future operational adjustments and upgrading Kadlec and Wallace (2008), Davis (1995), Bendoricchio et al. (2000).
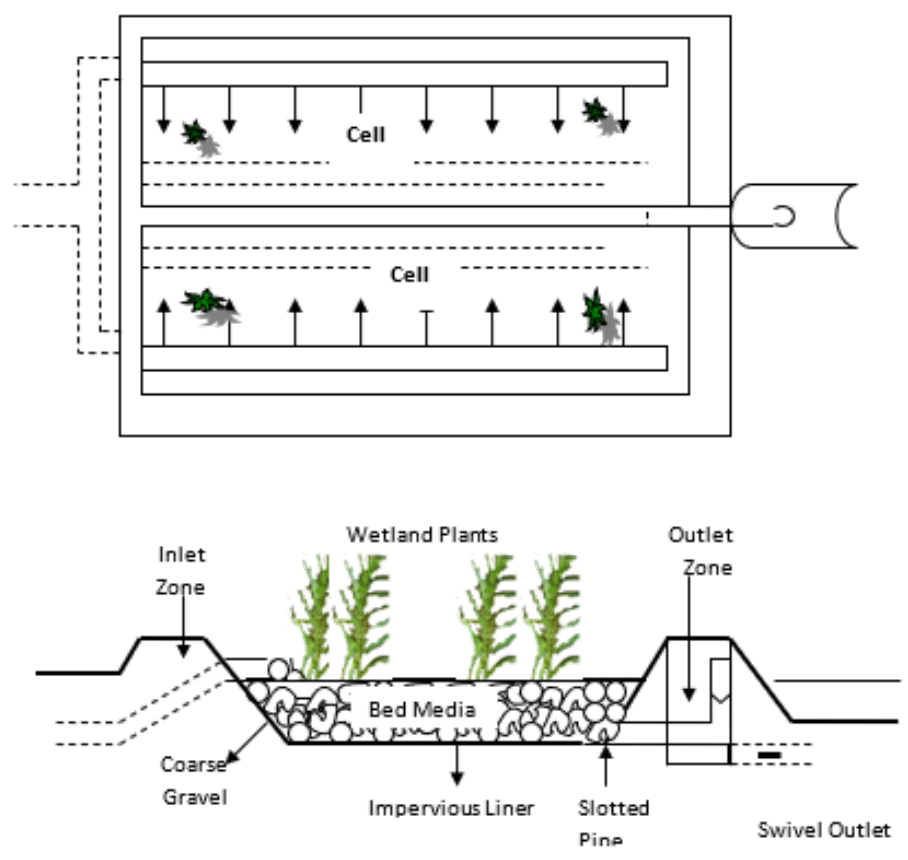

Figure 2 Plan and Cross-Sectional View of a Subsurface Flow Wetland Wallace and Knight (2006).

SSF constructed wetlands are best suited to treat wastewaters with relatively low solids concentrations and under relatively uniform flow conditions Because of the hydraulic constraints imposed by the substrate Vymazal (2011), Vymazal (2001), Scholz and Lee (2005), Davis (1995), Vymazal and Kröpfelová (2008),Wallace and Knight (2006).

\section{DESIGN VARIATIONS}

Design variations of constructed wetland affect shapes and sizes to fit match the site characteristics and optimize construction, operation, and enhance performance Carty et al. (2008). Constructed wetlands typically are fitted with liners to prevent infiltration, which depends on local soil conditions and regulatory requirements Kadlec and Wallace (2008). A large number of researches and studies have been published about constructed wetlands, nevertheless; the optimal design of constructed wetlands is still undetermined due to the absence of adequate monitoring systems and inadequate operating time to provide appropriate data for analysis Moreira and Dias (2020). In monitored systems, performance has fluctuated and the influences of the varied factors that affect performance, are the location, wastewater characteristic or runoff, the design of the wetland, climatic 
conditions, disturbance, and daily or seasonal changes are, challenging to estimate Kadlec and Wallace (2008), Davis (1995), Hammer (2014). Constructed wetland designs are most likely to mimic natural wetlands in all aspects of their structure in order to achieve high water quality of the treatment process Vymazal (2001), Hammer (2020). The planning phase is essential and important in constructed wetlands design variety of system types and configurations have been implemented to meet specific wastewater treatment needs, sites are often available, and a variety of native plant species can be selected. Moreover, each selected sites are unique and the design of a constructed wetland system will be site-specific Kadlec and Wallace (2008), Davis (1995), Hammer (2014), Hammer (2020).

Constructed wetlands require four components: liner, distribution media (substrate), vegetation, an under-drain system. The liner prevents water leakage and keeps the wastewater away from reaching the surrounding environment and groundwater. Generally, the liner is manufactured from a number of materials, and among the most common and reliable materials are polyvinyl chloride (PVC) (Figure 3) Davis (1995).

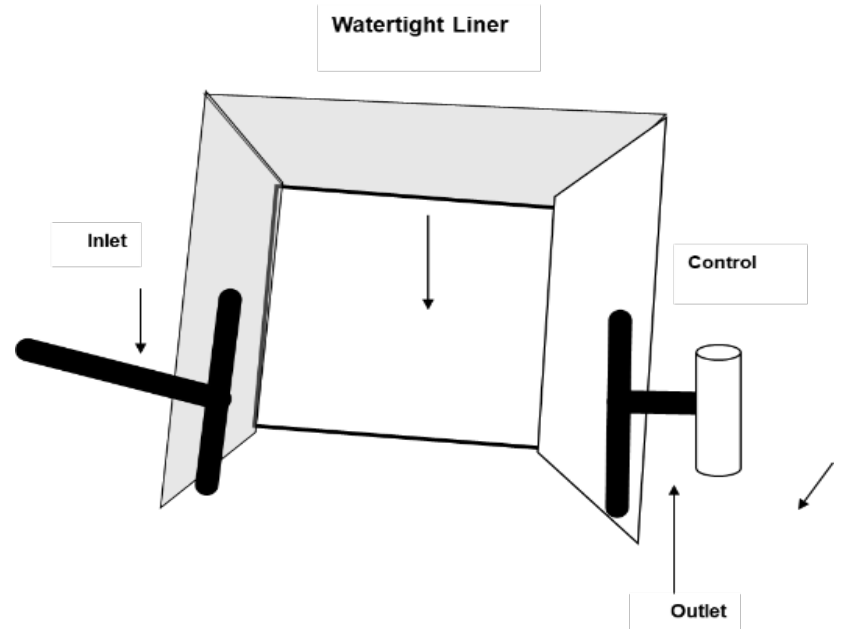

Figure 3 A Sectional View of Wetland Controls and Liner Davis (1995).

The inlet consists of a distribution medium which is usually coarse rock that is 2 to $5 \mathrm{~cm}$ in diameter. The first section of the distribution system spreads the wastewater influent across the width and the cross-section of the wetland. The filter contains a pea gravel media which is $1 \mathrm{~cm}$ to $2 \mathrm{~cm}$ in diameter Davis (1995). The pea gravel depth varies and it is usually in the range of $45 \mathrm{~cm}$ to $60 \mathrm{~cm}$. The under-drain system at the outlet of the wetland is a slotted $10 \mathrm{~cm}$ pipe covered with rock. The under-drain transfers the treated effluent out of the wetland and maintains the effluent level below the gravel surface to avoid direct contact with people and prevent mosquitoes from breeding in the wetland Davis (1995). Moreover, the water level stays high enough in order to sustain plant growth. (Figure 4 and Figure 5) depict the most common constructed wetland system design types 


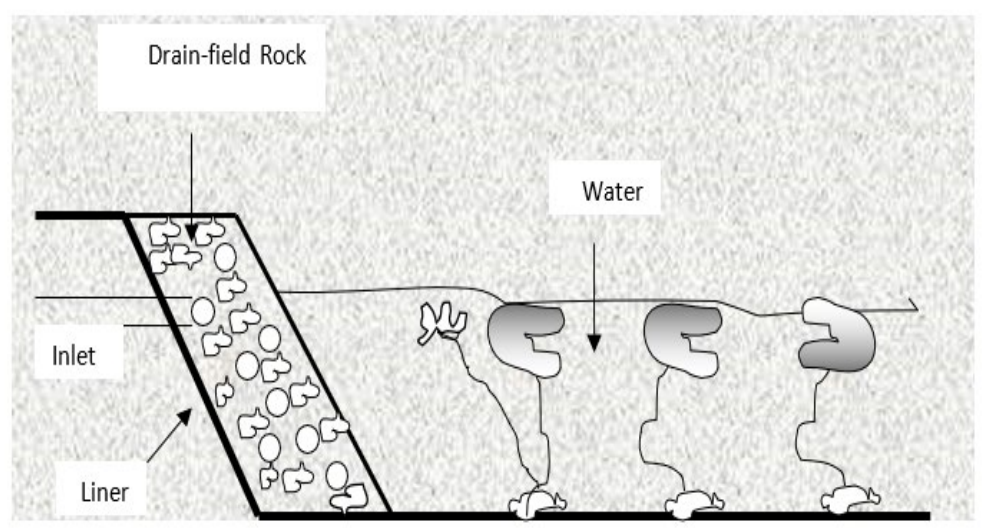

Figure 4 A Free Water Surface Flow Wetland Sketch Davis (1995)

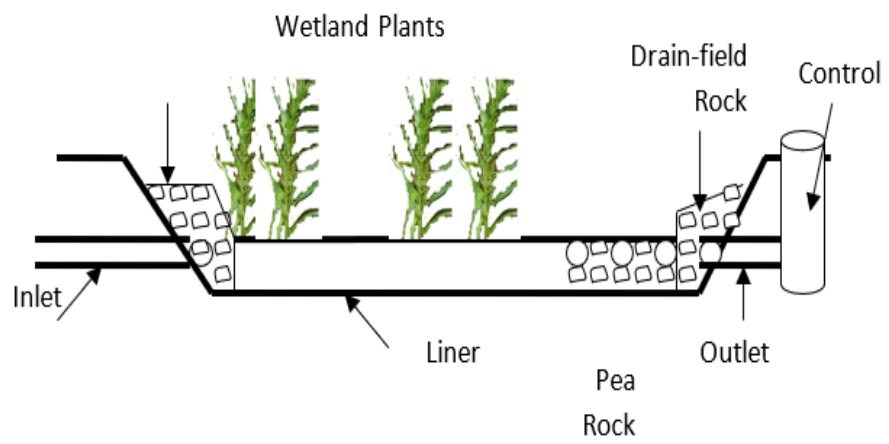

Figure 5 A Subsurface Flow Constructed Wetland Sketch Vymazal (2001)

The designing criteria for both systems are different as can be shown in (Table 3).

Table 3 Design Criteria for Constructed Wetlands LaFlamme (2006) , Crites (1994).

\begin{tabular}{cccc}
\hline Design parameter & Unit & Surface wetland & Subsurface wetland \\
\hline Retention time & $\mathrm{d}$ & 5 to 14 & 2 to 7 \\
\hline Water depth/ media depth & $\mathrm{M}$ & 0.1 to 0.8 & 0.3 to 0.6 \\
\hline Hydraulic loading rate & $\mathrm{mm} \mathrm{d}^{-1}$ & 15 to 65 & 80 to 300 \\
\hline Volume flow rate & $\mathrm{m}^{3} \mathrm{~d}^{-1}$ & 200 to 75000 & 5 to 13000
\end{tabular}

Source: [LaFlamme (2006)Crites (1994)]

Suggested design dimensions can be used for both wetland types as follows Kadlec and Wallace (2008), Davis (1995), Carty et al. (2008),Hammer (2020):

Surface Flow Wetland:

1) Surface area: $(10-20) \mathrm{m}^{2} .60 \mathrm{~g}-1 . \mathrm{d}-1$. dof total BOD5;

2) Water depth: $10-50 \mathrm{~cm}$;

3) Hydraulic retention time: minimum 10 days;

$\tau=\mathrm{L} \times \mathrm{W} \times \mathrm{D} / \mathrm{Q}$ (Volume of water $\mathrm{m} 3$ and the Flow $\mathrm{m}^{3} / \mathrm{d}$ );

4) Length/Width = minimum $4 / 1$. 
Subsurface Horizontal Flow Wetland:

1) Surface area: 5 - $10 \mathrm{~m}^{2}$ 60g-1. d-1of total BOD5;

2) Minimum Length is $6 \mathrm{~m}$; max Length is $15 \mathrm{~m}$;

3) The slope of the reed bottom is (1\%) from the top surface level;

4) Depth of the inlet: $\pm 0.6 \mathrm{~m}$; depth of the outlet: maximum depth $0.8 \mathrm{~m}$; minimum depth $0.3 \mathrm{~m}$.

\section{DESIGN CONSIDERATIONS}

In constructed wetlands, hydrology is considered the most important design parameter because it connects all of the functions and it is responsible for the success or failure of a constructed wetland Hammer (2020). Hydrology influences different components of the wetlands such abiotic components include water and nutrient availability, aerobic or anaerobic conditions of the soil, depth of water and velocity, and pH. Also, hydrology could affect biotic factors as water budget and gains through the interference of precipitation and losses through evapotranspiration through plants LaFlamme (2006), Hernandez and Mitsch (2007).

Water flows through the wetland resembling plug-flow than completely mixed flow Stairs (1993). Plug-flow conditions demands minimized short-circuiting and dead pools. Hydraulic retention time is a critical design element that assumes uniform flow behavior. Treatment wetlands are mainly designed to avoid stormwater runoff to flow through the wetland unless the intention is to treat storm-water runoff. Avoiding storm-water runoff can be achieved by placing the wetland in a highpoint and/or with the use of berms to divert storm-water runoff of the wetland inlet Davis (1995), Carty et al. (2008), Hammer (2014). Flow characteristics through the wetland comprise Davis (1995):

Velocity is controlled by a sloping bed that maintains an adequate hydraulic gradient through the wetland to achieve the desired velocity.

- Retention Time - is the time needed for a volume of water to travel from the inlet to the outlet of the wetland which is determined by the size, the depth, and the travel path through the wetland.

- Depth of Flow - it must be determined to offer adequate storage and appropriate conditions for the wetland plants.

- Travel Path - prevent short-circuiting through the system by providing an appropriate length to width ratio.

- Water Balance -the sources and sinks that will occur in the wetland must be determined. Groundwater influences are negligible due to the usage of the liners. It is important to the precipitation and evapotranspiration contribution must be determined in order to show the effect on the wetland hydrology.

Hydrological considerations include climate and weather, hydro-period, hydraulic retention time, hydraulic loading rate, groundwater exchanges (infiltration and deep percolation), losses to the atmosphere (evapotranspiration), and overall water balance Hammer (2014), Hammer (2020).

\section{LIMITATIONS OF WETLAND PROCESSES}

Biochemical and biological processes rate dependent on environmental factors, these factors include light period, temperature, dissolved oxygen, and $\mathrm{pH}$. Metabolic activities are negatively affected by short light periods and low temperature, which hinder the rate of pollutant uptake by biota Jing et al. (2001), Moreira and Dias 
(2020), Kadlec and Wallace (2008), LaFlamme (2006), Hernandez and Mitsch (2007). Low oxygen level limits disturb the aerobic respiration processes within the water column and may create anaerobic conditions Arndt et al. (2013). metabolic activities are affected by too high or too low $\mathrm{pH}$ - for that, they are dependent Kayombo et al. (2004). Outflow pollutant concentrations are occasionally zero, and in some cases for some parameters they can exceed inflow concentrations, because of the internal autotrophic processes of the wetland Vymazal (2007), Vymazal and Kröpfelová (2009).

Hydrology and hydraulics are the main driving forces behind the presence and functions of a constructed wetland. hydrology describes the quantity and temporal distribution of the flow from a watershed into a constructed wetland while, hydraulics is related to the patterns and velocities of water movement within a constructed wetland Braskerud (2002).

\subsection{HYDROLOGY}

Hydrology or the water processes that occur in the wetland are important to the design and maintain the successful operation of the constructed wetlands Scholz and Lee (2005), Tony et al. (1999).

There are two main considerations are:

- Water balance - FWS wetlands are subjected to water loss due to evapotranspiration and seepage and subjected to gains (rainfall) which cause a fluctuating in water volumes and levels within the wetland.

- Retention time - the period of time that wastewater is retained inside the wetland is critical to the various treatment processes that occur. Required retention times vary depending on the concentration of the pollutants and the desired level and the target of the treatment. it was suggested that the best retention times for BOD removal are 2 to 5 days and it was recommended for BOD and SS removal between 7 to 10 days Rowe and Abdel-Magid (2020). Moreover, it was recommended 1 to 3 days for coliform removal, and 7 to 14 days for nitrogen removal while $\mathrm{P}$ removal is unpredictable at any retention time Braskerud (2002).

\subsubsection{WATER BALANCE}

Water balance for a constructed wetland is an account of the total inflow, storage, and outflow of water. The inflow consists of either surface water (the wastewater or storm-water), groundwater infiltration (in unlined wetlands), and rainfall. Outflow comprises surface water evaporation, evapotranspiration by plants, effluent discharge, and infiltration into groundwater Davis (1995), Hammer (2020), Gorito et al. (2017). Effluent concentrations can be diluted by rainfall or increased by loss due to evaporation Vymazal (2011), Vymazal (2011), Vymazal (2001), Davis (1995). During design and operation, the constructed wetland water balance is important for determining conformance with desired limits for hydraulic loading rate, hydro-period range, hydraulic retention time (HRT), and mass balances Kadlec and Wallace (2008), Davis (1995), Hammer (2020). The water balance equation for a constructed wetland can be expressed as:

$$
\mathbf{S}=\mathbf{Q}+\mathbf{R}+\mathbf{I}-\mathbf{O}-\mathbf{E} \mathbf{T}
$$

Where: $S=$ net change in storage

$\mathrm{Q}=$ surface flow, including wastewater or storm-water inflow,

$\mathrm{R}=$ contribution from rainfall

$\mathrm{I}=$ net infiltration (infiltration less exfiltration) 
O = surface outflow

ET= loss due to evapotranspiration.

Constructed wetlands are appropriate for tools for measuring water balance and ET due to having distinct inflow and outflow, and homogeneous substrate and vegetation Drexler et al. (2004). wetlands make up a large portion of the land use and ET is accounted for between $55-80 \%$ of water yield in some watersheds Białowiec et al. (2014).

\subsubsection{HYDRAULIC RETENTION TIME HRT}

Water treatment processes depend on the period of time that wastewater physically resides within the wetland boundaries Almuktar et al. (2018). This period is known as retention time or could be defined in literature as hydraulic retention time, or detention time. Retention time can be obtained from the following equation:

$$
t=\frac{\mathrm{ny} \cdot \mathrm{dA}}{\mathrm{Q} a v}
$$

Where, $\mathrm{t}=$ average retention time (days) $=(\mathrm{tn})=$ nominal retention time

$\mathrm{nv}=$ void ratio or porosity, corresponding to proportion of typical wetland cross section not occupied by vegetation. Typically, equal to 0.65 to 0.75

$\mathrm{d}=$ wetland water depth $(\mathrm{m})$

$\mathrm{A}=$ wetland surface area $(\mathrm{m} 2)$

Qav = average discharge (m3/day) or equal to the average of Qi and Qo to water balance transit of the bed Davis (1995).

The effectiveness of (biological, chemical, and physical) processes vary with the water retention time It was reported that longer retention times accelerate the removal of more contaminants, though too-long retention times can have negative effects Kayombo et al. (2004). It was mentioned in the literature and based on empirical experiences that it should be at least 3-5 days during normal high-water periods. Moreover, some reported that constructed wetlands with average retention times of less than 2 days should not be made if the purpose is nitrogen removal Koskiaho et al. (2009). In practice, water balance changes (e.g., varying influent discharges, rainfall, and evaporation conditions that combine to change effluent discharges) fluctuate retention time Scholz and Lee (2005), Davis (1995), Hammer (2020). In practice, $t$ is the period during which all of the water flowing into the wetland at a specific time and with an equal flow velocity Kadlec and Wallace (2008).

\subsubsection{HYDRAULIC LOADING RATE HLR}

Hydraulic loading is a measure of the volumetric application of wastewater into the wetland. It is often used to make comparisons between wetland systems and indicates their potential to be overloaded by wastewater Dong et al. (2011). The hydraulic loading rate can be calculated by the following equation.

$$
H L R=Q / A
$$

Where: HLR = hydraulic loading rate $(\mathrm{m} /$ day $)$ 


$$
\begin{aligned}
& \text { Qi = influent wastewater flow (m3/day) } \\
& \text { In some cases, Qav is used instead of Qi, } \\
& \text { A = wetland surface area (m2) Davis (1995). }
\end{aligned}
$$

Both HLR and HRT play a major role in the extent of the interaction between wastewater and the constructed wetland system Toet et al. (2005). In natural wetlands, HLR must be in the range of 1 to $2 \mathrm{~cm} /$ day to minimize vegetative changes and enhance treatment to reach maximum treatment efficiency. on the other hand, hydraulic loading between $2.5-5 \mathrm{~cm}$ /day was optimal for FWS wetland and 6-8 cm/day for SSF wetlands Rowe and Abdel-Magid (2020).

\subsection{PRECIPITATION IMPACTS}

Precipitation and snowmelt can increase the flow in constructed wetland systems. It is very important to determine and estimate the runoff in areas with extended periods of precipitation and must be included in the design flow. Precipitation dilutes pollutants and washes out the chemical in the system, which raises the water level and decrease the HRT which deteriorate the efficiency of the wetland Davis (1995), Hammer (2020).

\subsection{EVAPOTRANSPIRATION}

Evapotranspiration (ET) is the water loss to the atmosphere from the water surface and from the soil (evaporation) and the loss of water from the vegetation of the wetland plants (transpiration).

ET is an important factor in wetland design. It affects the overall water balance of a waste treatment system, thus decreasing efficiency Davis (1995), Vymazal and Kröpfelová (2008). Usually, evaporation slows the water in the system, and that could significantly increase in retention time of the wetland. Due to high evaporation, the accumulation of concentrated pollutants could reach toxic levels if the water loss from the wetland exceeds the inflow. To reverse the effect of water loss, water must be supplied in order to keep the wetland wet and keep the wastewater treatment efficient and durable Davis (1995), Vymazal and Kröpfelová (2008).

\section{HOW WETLANDS IMPROVE WATER QUALITY}

Wetland is a complex and sophisticated system with combinations of water, substrate, plants and plants debris and litter, invertebrates, and microorganisms Moreira and Dias (2020), Vymazal (2010), Vymazal (2007), Vymazal (2001),Vymazal and Kröpfelová (2008), Vymazal and Kröpfelová (2009). Many physical, chemical, and biological processes occurred within treatment wetlands. The processes vary in simplicity and in complexity which makes them not fully understood in terms of the contribution to the treatment process Vymazal (2010), Kadlec and Wallace (2008), Hammer (2020). Normally, the driving factor in determining the limiting pollutant for which the wetland should be designed is the treatment level which must be very efficient to reach discharge permit requirements Davis (1995). Treatment performance of the wetlands could be judged by the capabilities and the percentage of mass removal of contaminants and depends on the contaminant concentration in the wetland outflow It is important that the selected criteria accurately reflect the actual performance of the wetland relative to the objectives and intended uses of the wetland treatment system Dotro 
et al. (2017). However, justification conducted on experimental results obtained from a sub-surface flow constructed wetland showed that the first few years of the constructed wetland performance is related to the initial operating stage Awad and Saleh (2001).

Immobilization and/or transformation of pollutants in constructed wetlands usually occur due to some physical, chemical, and biological processes which take place in the substrate-water matrix and in the plant rhizosphere Vymazal et al. (2006). Constructed wetlands can efficiently remove the following components from wastewaters: suspended solids, organic matter, and excess nutrients, as well as natural remains of pathogens Vymazal et al. (2006). SSF constructed wetland overtakes the FWS wetland in terms of numerous pollutants' removal. SSF wetlands have high performance to remove nutrients and chemicals. Jindal and Samorkhom, 2005 showed the same trend of higher removal efficiencies of chemical oxygen demand (COD), total Kjeldahl nitrogen TKN, total phosphorus (TP), total suspended solids TSS, volatile suspended solids VSS, and Cadmium removal efficiencies in both SSF wetland and FWS wetland Jindal and Samorkhom (2005). Constructed wetlands are considered an accepted low-cost technology for removing phosphorus from wastewater Jindal and Samorkhom (2005). Constructed wetlands are considered an accepted low-cost technology for removing phosphorus from wastewater Vymazal (2011), Vymazal (2010), Davis (1995), Almuktar et al. (2018). Researchers have examined the use of various materials as potential substrates to enhance phosphorus $\mathrm{P}$ removal by constructed wetland treatment systems. Further researchers have shown the addition of P-sorbing materials in separate rechargeable cells of the wetlands to improve the ability and sustainability of constructed wetlands to remove P from wastewater Zhu et al. (2003). This could be a cheap way to improve the performance, sustainability, and durability of constructed wetlands or could be used to minimize the wetland area for a given level of treatment Leader et al. (2005). Constructed wetland plants showed 80 to $90 \%$ removal efficiency of COD was shown at temperatures greater than $12^{\circ} \mathrm{C}$. Moreover, emergent plants have shown high ammonia and phosphate removal efficiency. Only planted wetland cells exhibited significant long-term phosphate removal Stein et al. (1998),Yang et al. (2007), suggested that plant growth and development of fine root biomass were associated with the removal efficiency in SFW wetlands. The same author concluded that selecting highly effective wetland plants significantly depends on the development of fine roots biomass Stein et al. (1998), Yang et al. (2007). Jing et al. (2002) examined the effect of different hydraulic loading rates HLR and macrophytes type on the removal efficiency of COD, ammonia-N, and PO4$P$, exhibited that planted systems are more efficient in nutrient removal than the unplanted systems; nevertheless, the type of macrophyte did not make a major contribution to the treatment Jing et al. (2002). The interacting effect of temperature and plant type on nutrient removal in wetlands was also studied. It was reported that nutrient removal efficiency depends on seasonal variation. More nutrients were removed in warmer seasons compared to the colder ones. Planted microcosms overtook the unplanted microcosms, which proves the significance of macrophysics in a wetland Khanijo (2002). Microbiological pollution removal in the wetlands is infrequently a primary target for constructed treatment wetlands Vymazal and Health (2005). However, wetlands are very effective in removing pathogens, typically reducing the pathogen number by up to five folds from wetland inflows Kayo mbo et al. (2004). Wetlands are known to offer appropriate physical, chemical, and biological conditions for the removal of pathogenic organisms Vymazal and Kröpfelová (2008). Removal of pathogens (indicators) in wetlands is correlated with TSS removal and HRT. HRT Required for pathogens removal varies depending 
on the nature of the pollutant and the level of treatment required. For design purposes, a two-log reduction is a practical approximation of vegetated submerged bed systems' performance. Peak flows in response to extreme rainfall events also disturb and decrease the removal efficiencies for fecal coliforms Davis (1995). It was shown by a study that $87 \%$ of the variance in E. coli concentrations across five monitored rainfall events with a positive correlation between solar radiation and E. coli concentratio Smith et al. (1998).

\section{OPERATION AND MAINTENANCE}

Constructed wetlands require routine maintenance which includes inspecting all components and cleaning and repairing the system when needed Sundaravadivel et al. (2001). The decision-maker needs to keep certain records on operation and maintenance as an aid to ensuring that the system continues to function as efficiently and required. At least, the inlet and the outlet pipes should be inspected on daily basis to avoid clogging by various types of debris which could be problematic Scholz and Lee (2005), Kadlec and Wallace (2008), Davis (1995),Carty et al. (2008). The most critical items in which operator intervention is necessary are:

- Water level adjustment

- Maintenance of inlet and outlet structures to keep flow uniformity

- Management practices to preserve vegetation

- Control of Odor

- Control of nuisance pests and insects

- Regular maintenance of berms and dikes Davis (1995), Carty et al. (2008)

\section{PROS AND CONS OF USING CONSTRUCTED WETLANDS}

In general, the final decision on whether to apply and adopt wetland technology has to be made in the situation of the overall treatment process (i.e., what other (primary) treatment measures are being adopted) and the available area and land. Constructed wetlands demand cautious management which enhances the water treatment capability of the wetland Aslam et al. (2004). Table 4 depicts the main advantages and disadvantages of using constructed wetlands.

\begin{tabular}{|c|c|}
\hline Advantages & Disadvantages \\
\hline Very low operational costs & $\begin{array}{l}\text { Capital is ranging from medium to high costs are medium } \\
\text { to high. }\end{array}$ \\
\hline very low energy and materials inputs & Require large area and lands \\
\hline $\begin{array}{l}\text { Different treatment processes are } \\
\text { available } \\
\text { can stand a wide range of pollutants } \\
\text { and toxicants }\end{array}$ & $\begin{array}{l}\text { Operational control over treatment processes is limited } \\
\text { may accumulate toxic substances in the sediments and } \\
\text { may contamination of the site }\end{array}$ \\
\hline $\begin{array}{l}\text { Considered a natural, sustainable } \\
\text { and suitable practice for polluted } \\
\text { and wastewater treatment. }\end{array}$ & $\begin{array}{l}\text { They are mimicking natural ecosystems and usually have } \\
\text { seasonally activity patterns which may result in seasonal } \\
\text { variations in performance. }\end{array}$ \\
\hline
\end{tabular}


Constructed wetlands for

wastewater treatment may act as

useful wildlife habitats and preserve nature
Attracting some wildlife to wetlands constructed for wastewater treatment performance through secondary contamination of water or through physical damage of wetland vegetation by wildlife.

Depending on the actual site, the use of high trees and shrubs can interject flight routes and sight lines and reduce the systems habitat value for certain species.

(Source: Merz (2000)).

\section{CONSTRUCTED WETLAND'S ROLE IN WILDLIFE ENHANCEMENT}

Constructed wetlands draw wildlife. Many birds, mammals, amphibians, reptiles, and a variety of insects adopt the area and consider the wetland as home. While any arrangement of cells enhances wildlife habitat, the layout can be modified to certain conditions to attract specific types of wildlife. In areas where bio-security is a concern, consideration should be given to excluding migratory and other nonresident wildlife to minimize the potential for the spread of disease to other operations. An EPA publication EPA U. (1999) indicated that more than 1,400 species of wildlife had been branded for constructed and natural treatment wetlands and considered it home. They include 700 species of invertebrates, 78 species of fish, 21 species of amphibians, 31 species of reptiles, 412 species of birds, and 40 species of mammals. More than 800 species were reported in constructed wetlands alone EPA U. (1999).

\section{AESTHETICS AND OTHER ANCILLARY BENEFITS OF CONSTRUCTED WETLANDS}

Wetlands have a unique beauty. Even when planted with typical plantings, the character of the system changes as natural wild plants invades the system. While the choice of plants may be limited for the initial or upstream segments of the system because of the high concentrations of some pollutants, more colorful and a greater variety of plant species may be placed at downstream locations within the wetland system where wastewater quality improves.

In addition to water quality improvement, constructed wetlands are known to produce ancillary benefits like aesthetic improvement of landscape, increased biodiversity, recreational uses, and possibilities for hunting Koskiaho (2009). The designer can incorporate additional features into the wetland system that do not detract from the primary goal of wastewater treatment. Some of these benefits include aesthetic appeal, educational value, recreational outlets, and habitat value. Interpretive centers can be incorporated into the wetland design to provide educational opportunities on such topics as energy conservation, wastewater treatment, wetland ecology, and pollution prevention. If the wetland designer wishes to incorporate these aspects into the wetland design, planning must include a safe means of public access Zedler and Kercher (2005).

\section{ECONOMIC BENEFITS OF CONSTRUCTED WETLANDS}

The usage of constructed wetlands depends on whether that treatment option is more cost-effective than other available or conventional treatment technologies. Each operation must be evaluated exclusively to determine if the installation of a 
constructed wetland will provide an additional economic values benefit. Even if an economic analysis shows no net benefit from installing a constructed wetland, some decision-makers might be willing to forgo some measure of annual benefit to reduce the amount of time spent in waste handling Zhang et al. (2009).

Some key factors that must be considered in an economic assessment include Vymazal (2011), Vymazal (2010), Wallace and Knight (2006):

- Construction costs,

- Value of nutrients lost through treatment by the wetland,

- Equipment and labor costs to land apply wastewater,

- Value of land used by constructed wetland,

- Value of crop lost because of land taken out of production by the CW, and

- Cost of maintenance and operation.

\section{CONCLUSION}

Constructed wetlands are among the recently demonstrated technologies to have a great potential for efficient wastewater treatment and management in rural and developed areas. When properly designed and operated, constructed wetlands have great advantages over conventional treatment systems for their relatively low cost, easy operation, and maintenance.

\section{REFERENCES}

Almuktar, S.A.A.A.N., S.N. Abed, and M. Scholz, (2018) Wetlands for wastewater treatment and subsequent recycling of treated effluent: a review. Environmental Science and Pollution Research. 25(24): p. 23595-23623. Retrieved from https://doi.org/10.1007/s11356-018-2629-3

Arndt, S., et al., (2013) Quantifying the degradation of organic matter in marine sediments: a review and synthesis. Earth-science reviews. 123: p. 53-86. Retrieved from https://doi.org/10.1016/j.earscirev.2013.02.008

Aslam, M.M., et al., (2004) Constructed Treatment Wetlands: An Option for Wastewater Treatment in Pakistan. Electronic Journal of Environmental, Agricultural Food Chemistry. Retrieved from https://www.researchgate.net/profile/Muhammad-MasudAslam/publication/267304211_CONSTRUCTED_TREATMENT_WETLANDS _AN_OPTION_FOR_WASTEWATER_TREATMENT_IN_PAKISTAN/links/56f1 2f7408aec9e096b31335/CONSTRUCTED-TREATMENT-WETLANDS-ANOPTION-FOR-WASTEWATER-TREATMENT-IN-PAKISTAN.pdf

Awad, A.M. and H.I. Saleh, (2001) Evaluating contaminants removal rates in subsurface flow constructed wetland in Egypt, in Wetlands Engineering \& River Restoration. $\quad$ p. 1-10. $\quad$ Retrieved from https://doi.org/10.1061/40581(2001)61

Bastian, R. and D. Hammer, (2020) The use of constructed wetlands for wastewater treatment and recycling, in Constructed wetlands for water quality improvement. CRC Press. p. 59-68. Retrieved from https://doi.org/10.1201/9781003069997-6

Batool, A. and T.A. Saleh, (2020). Removal of toxic metals from wastewater in constructed wetlands as a green technology; catalyst role of substrates and chelators. Ecotoxicology environmental safety. 189: p. 109924. Retrieved from https://doi.org/10.1016/j.ecoenv.2019.109924 
Bendoricchio, G., L. Cin, and J. Persson, (2000) Guidelines for free water surface wetland design. EcoSys Bd, 2000. 8: p. 51-91. Retrieved from https://www.researchgate.net/profile/Jesper-Persson-

2/publication/268441082_Guidelines_for_free_water_surface_wetland_des ign/links/54bcd7b90cf253b50e2d690b/Guidelines-for-free-water-

surface-wetland-design.pdf

Białowiec, A., A. Albuquerque, and P.F. Randerson, (2014) The influence of evapotranspiration on vertical flow subsurface constructed wetland performance. Ecological Engineering,. 67: p. 89-94. Retrieved from https://doi.org/10.1016/j.ecoleng.2014.03.032

Braskerud, B.E.E., (2002) Factors affecting phosphorus retention in small constructed wetlands treating agricultural non-point source pollution.. 19(1): p. 41-61. Retrieved from https://doi.org/10.1016/S09258574(02)00014-9

Brix, H. (2003) Plants used in constructed wetlands and their functions. in 1st International Seminar on the use of Aquatic Macrophytes for Wastewater Treatment in Constructed Wetlands, edit. Dias V., Vymazal J. Lisboa, Portugal. Retrieved from https://www.researchgate.net/profile/HansBrix/publication/230563384_Plants_used_in_constructed_wetlands_and_t heir_functions/links/00b4952c01bcfede04000000/Plants-used-inconstructed-wetlands-and-their-functions.pdf

Brix, H., (1997) Do macrophytes play a role in constructed treatment wetlands? Water Science and Technology,. 35(5): p. 11-17. Retrieved from https://doi.org/10.2166/wst.1997.0154

Brix, H., (1994) Functions of macrophytes in constructed wetlands. Water Science Technology. 29(4): p. 71-78. Retrieved from https://doi.org/10.2166/wst.1994.0160

Carty, A., et al., (2008) The universal design, operation and maintenance guidelines for farm constructed wetlands (FCW) in temperate climates. Bioresource technology. 99(15): p. 6780-6792. Retrieved from https://doi.org/10.1016/j.biortech.2008.01.045

Coban, O., et al., (2015) Nitrogen transforming community in a horizontal subsurface-flow constructed wetland. 74: p. 203-212. Retrieved from https://doi.org/10.1016/j.watres.2015.02.018

Crites, R.W., (1994) Design Criteria and Practice for Constructed Wetlands. Water Science and Technology. 29(4): p. 1-6. Retrieved from https://doi.org/10.2166/wst.1994.0144

Cui, L., et al., (2015) Removal of nutrients from septic tank effluent with baffle subsurface-flow constructed wetlands. Journal of environmental management. 153: p. 33-39. Retrieved from https://doi.org/10.1016/j.jenvman.2015.01.035

Davis, L., (1995) A handbook of constructed wetlands: a guide to creating wetlands for: agricultural wastewater, domestic wastewater, coal mine drainage, stormwater in the Mid-Atlantic Region. Retrieved from https://agris.fao.org/agris-search/search.do?recordID=US9618124

Dhote, S. and S. Dixit, (2009) Water quality improvement through macrophytes-a review. Environmental monitoring assessment. 152(1): p. 149-153. Retrieved from https://doi.org/10.1007/s10661-008-0303-9

Dong, Y., et al., (2011) Impact of hydraulic loading rate and season on water contaminant reductions within integrated constructed wetlands. Wetlands. 
31(3): p. 499-509. Retrieved from https://doi.org/10.1007/s13157-0110176-5

Dotro, G., et al., (2017) Treatment wetlands: IWA publishing. Retrieved from http://library.oapen.org/handle/20.500.12657/31049

Drexler, J.Z., et al., (2004) A review of models and micrometeorological methods used to estimate wetland evapotranspiration. Hydrological processes. 18(11): p. 2071-2101. Retrieved from https://doi.org/10.1002/hyp.1462

EPA, U., (1999) Free Water Surface Wetlands for Wastewater Treatment A Technology Assessment. , W. Office of Research and Development, D.C., Editor. EPA.

Fonder, N. and T. Headley, (2013) The taxonomy of treatment wetlands: A proposed classification and nomenclature system. Ecological Engineering. 51: p. 203211. Retrieved from https://doi.org/10.1016/j.ecoleng.2012.12.011

Forslund, A., et al., (2009) Securing water for ecosystems and human well-being: The importance of environmental flows. Swedish Water House Report,. 24. Retrieved from http://hdl.handle.net/10535/5141

Galbraith, H., P.H. Amerasinghe, and A. Huber-Lee, (2005) The Effects of Agricultural Irrigation on Wetland Ecosystems in Developing Countries: A Literature Review. Retrieved from http://hdl.handle.net/10535/5054

Gorito, A.M., et al., (2017) A review on the application of constructed wetlands for the removal of priority substances and contaminants of emerging concern listed in recently launched EU legislation. J Environmental Pollution. 227: p. 428-443. Retrieved from https://doi.org/10.1016/j.envpol.2017.04.060

Greenaway, M., (2001) Changes in plant biomass and nutrient removal over 3 years in a constructed wetland in Cairns, Australia. J Water Science Technology. 44(11-12): $\quad$ p. 303-310. $\quad$ Retrieved https://doi.org/10.2166/wst.2001.0844

Hammer, D.A., (2020) Constructed wetlands for wastewater treatment: municipal, industrial and agricultural: CRC Press. Retrieved from https://doi.org/10.1201/9781003069850

Hammer, D.A., (2014) Creating freshwater wetlands: CRC Press. Retrieved from https://doi.org/10.1201/9781498710800

Healy, M.G., J. Newell, and M. Rodgers, (2007) HARVESTING EFFECTS ON BIOMASS AND NUTRIENT RETENTION IN PHRAGMITES AUSTRALIS IN A FREEWATER SURFACE CONSTRUCTED WETLAND IN WESTERN IRELAND. Biology and Environment: Proceedings of the Royal Irish Academy. 107B(3): p. 139-145. Retrieved from https://doi.org/10.3318/BIOE.2007.107.3.139

Hernandez, M.E. and W. Mitsch, (2007) Denitrification in created riverine wetlands: Influence of hydrology and season. Ecological Engineering. 30(1): p. 78-88. Retrieved from https://doi.org/10.1016/j.ecoleng.2007.01.015

Hernandez, M.E. and W. Mitsch, (2007) Denitrification in created riverine wetlands: Influence of hydrology and season. J Ecological Engineering. 30(1): p. 78-88. Retrieved from https://doi.org/10.1016/j.ecoleng.2007.01.015

Jindal, R. and N. Samorkhom, (2005) Cadmium Removal from Wastewater in Constructed Wetlands. 9(3): p. 173-178. Retrieved from https://doi.org/10.1061/(ASCE)1090-025X(2005)9:3(173)

Jing, S.-R., et al., (2001) Nutrient removal from polluted river water by using constructed wetlands. 76(2): p. 131-135. Retrieved from https://doi.org/10.1016/S0960-8524(00)00100-0 
Jing, S.R., et al., (2002) Microcosm wetlands for wastewater treatment with different hydraulic loading rates and macrophytes. Journal of Environmental Quality. 31(2): p. 690-696. Retrieved from https://doi.org/10.2134/jeq2002.6900 https://doi.org/10.2134/jeq2002.0690

Kadlec, R.H. and S. Wallace, (2008) Treatment wetlands: CRC press. Retrieved from https://doi.org/10.1201/9781420012514

Kayombo, S., et al., (2004) Waste stabilization ponds and constructed wetlands: design manual. Retrieved from https://stgwedocs.unep.org/bitstream/handle/20.500.11822/8380/-

Waste $\% 20$ Stabilization $\% 20$ Ponds\%20and\%20Constructed $\% 20$ Wetlands_ \%20Design\%20 Manual-20043595.pdf?sequence=3

Khanijo, I., (2002) Nutrient removal from waste water by wetland system. Wetlands. 10: p. 1-12. Retrieved from http://home.eng.iastate.edu/ tge/ce421521/ishadeep.pdf

Koskiaho, J., M. Puustinen, and N. Kotamäki, (2009) Retention performance of a constructed wetland as measured automatically with sensors. Prog. Environ. Sci. Technol,. $\quad$ Retrieved from https://www.researchgate.net/profile/Jari-

Koskiaho/publication/235752144_Retention_performance_of_a_construct ed_wetland_as_measured_automatically_with_sensors/links/0fcfd5131f39 aee8ea000000/Retention-performance-of-a-constructed-wetland-asmeasured-automatically-with-sensors.pdf

LaFlamme, C., (2006) Nutrient removal using a constructed wetland in Southern Québec.. Retrieved from https://escholarship.mcgill.ca/concern/theses/db78tc27r

Leader, J.W., K.R. Reddy, and A.C. Wilkie, (2005) Optimization of low-cost phosphorus removal from wastewater using co-treatments with constructed wetlands. Water Science and Technology. 51(9): p. 283-290. Retrieved from https://doi.org/10.2166/wst.2005.0338

Merz, S.K., (2000) Guidelines for using free water surface constructed wetlands to treat municipal sewage: Department of Natural Resources.

Moreira, F.D. and E.H.O. Dias, (2020) Constructed wetlands applied in rural sanitation: A review. Environmental Research. 190: p. 110016. Retrieved from https://doi.org/10.1016/j.envres.2020.110016

Pezeshki, S.R., (2001) Wetland plant responses to soil flooding. Environmental and Experimental Botany. 46(3): p. 299-312. Retrieved from https://doi.org/10.1016/S0098-8472(01)00107-1

Rowe, D.R. and I.M. Abdel-Magid, (2020) Handbook of wastewater reclamation and reuse: CRC press. Retrieved from https://doi.org/10.1201/9780138752514

Scholz, M. and B.h. Lee, (2005) Constructed wetlands: a review. International Journal of Environmental Studies. 62(4): p. 421-447. Retrieved from https://doi.org/10.1080/00207230500119783

Sirianuntapiboon, S. and S. Jitvimolnimit, (2007) Effect of plantation pattern on the efficiency of subsurface flow constructed wetland (SFCW) for sewage treatment. African Journal of Agricultural Research. 2(9): p. 447-454. Retrieved from https://doi.org/10.5897/AJAR.9000215

Smith, M., R. Allen, and L. Pereira, (1998) Revised FAO methodology for crop-water requirements.. from https://www.osti.gov/etdeweb/biblio/676839 
Stairs, D.B., (1993) Flow characteristics of constructed wetlands: Tracer studies of the hydraulic regime. Retrieved from https://ir.library.oregonstate.edu/concern/graduate_thesis_or_dissertatio ns /pn89d909g

Stein, O.R., et al., (1998) Performance Data from Model Constructed Wetlands for Wastewater Treatment, in Engineering Approaches to Ecosystem Restoration. $\quad$ p. 949-954. $\quad$ Retrieved from https://doi.org/10.1061/40382(1998)158

Stottmeister, U., et al., (2003) Effects of plants and microorganisms in constructed wetlands for wastewater treatment. Biotechnology Advances. 22(1): p. 93117. Retrieved from https://doi.org/10.1016/j.biotechadv.2003.08.010

Sundaravadivel, M., S. Vigneswaran, and technology, (2001) Constructed wetlands for wastewater treatment. Critical reviews in environmental science technology. 31(4): p. 351-409. Retrieved from https://doi.org/10.1080/20016491089253

Tanner, C.C., (1996) Plants for constructed wetland treatment systems - A comparison of the growth and nutrient uptake of eight emergent species. Ecological Engineering. 7(1): p. 59-83. Retrieved from https://doi.org/10.1016/0925-8574(95)00066-6

Toet, S., et al., (2005) The effect of hydraulic retention time on the removal of pollutants from sewage treatment plant effluent in a surface-flow wetland system. Wetlands. 25(2): p. 375-391. Retrieved from https://doi.org/10.1672/13

Tony, H.F.W., C.C.R.C.f.C. Hydrology, and T. Wong, (1999) Managing urban stormwater using constructed wetlands: Cooperative Research Centre for Catchment Hydrology. Retrieved from https://www.researchgate.net/profile/Peter-Breen-

2/publication/237341383_Managing_Urban_Stormwater_Using_Construct ed_Wetlands/links/0c960533ea34ca8cf4000000/Managing-Urban-

Stormwater-Using-Constructed-Wetlands.pdf

Truu, M., J. Juhanson, and J. Truu, (2009) Microbial biomass, activity and community composition in constructed wetlands. Science of The Total Environment. 407(13): p. 3958-3971. Retrieved from https://doi.org/10.1016/j.scitotenv.2008.11.036

Vymazal, J. and Health, (2005) Removal of enteric bacteria in constructed treatment wetlands with emergent macrophytes: a review. Journal of Environmental Science. 40(6-7): p. 1355-1367. Retrieved from https://doi.org/10.1081/ESE-200055851

Vymazal, J. and L. Kröpfelová, (2009) Removal of nitrogen in constructed wetlands with horizontal sub-sureface flow: a review. Wetlands. 29(4): p. 1114-1124. Retrieved from https://doi.org/10.1672/08-216.1

Vymazal, J. and L. Kröpfelová, (2008) Wastewater treatment in constructed wetlands with horizontal sub-surface flow. Vol. 14: Springer science \& business media. Retrieved from https://doi.org/10.1007/978-1-40208580-2

Vymazal, J., (2010) Constructed Wetlands for Wastewater Treatment. 2(3): p. 530549. Retrieved from https://doi.org/10.3390/w2030530

Vymazal, J., (2011) Constructed Wetlands for Wastewater Treatment: Five Decades of Experience. Environmental Science \& Technology. 45(1): p. 61-69. Retrieved from https://doi.org/10.1021/es101403q 
Vymazal, J., (2011) Constructed wetlands for wastewater treatment: five decades of experience. J Environmental science and technology. 45(1): p. 61-69. Retrieved from https://doi.org/10.1021/es101403q

Vymazal, J., (2013) Emergent plants used in free water surface constructed wetlands: A review. Ecological Engineering. 61: p. 582-592. Retrieved from https://doi.org/10.1016/j.ecoleng.2013.06.023

Vymazal, J., (2011) Plants used in constructed wetlands with horizontal subsurface flow: a review. Hydrobiologia. 674(1): p. 133-156. Retrieved from https://doi.org/10.1007/s10750-011-0738-9

Vymazal, J., (2007) Removal of nutrients in various types of constructed wetlands. Science of The Total Environment. 380(1): p. 48-65. Retrieved from https://doi.org/10.1016/j.scitotenv.2006.09.014

Vymazal, J., (2001) Types of constructed wetland for wastewater treatment: Their potential for nutrient removal. The Netherlands: Backhuys Publishers. Retrieved from https://ci.nii.ac.jp/naid/10019173782/

Vymazal, J., et al., (2006) Constructed Wetlands for Wastewater Treatment, in Wetlands and Natural Resource Management, J.T.A. Verhoeven, et al., Editors, Springer Berlin Heidelberg: Berlin, Heidelberg. p. 69-96. Retrieved from https://doi.org/10.1007/978-3-540-33187-2_5

Wallace, S. and R.L. Knight, (2006) Feasibility, design criteria, and O\&M requirements for small scale constructed wetland wastewater treatment systems: Water Environment Research Foundation. Retrieved from https://doi.org/10.2166/9781780403991

Yalcuk, A. and A. Ugurlu, (2009) Comparison of horizontal and vertical constructed wetland systems for landfill leachate treatment. Bioresource Technology. 100(9): $\quad$ p. 2521-2526. from https://doi.org/10.1016/j.biortech.2008.11.029

Yang, Q., et al., (2007) Contaminant Removal of Domestic Wastewater by Constructed Wetlands: Effects of Plant Species. 49(4): p. 437-446. Retrieved from https://doi.org/10.1111/j.1744-7909.2007.00389.x

Yang, Y., et al., (2018) Global development of various emerged substrates utilized in constructed wetlands. Bioresource Technology. 261: p. 441-452. Retrieved from https://doi.org/10.1016/j.biortech.2018.03.085

Zedler, J.B. and S. Kercher, (2005) Wetland resources: status, trends, ecosystem services, and restorability. Annu. Rev. Environ. Resour. 30: p. 39-74. Retrieved https://doi.org/10.1146/annurev.energy.30.050504.144248

Zhang, D., R.M. Gersberg, and T.S. Keat, (2009) Constructed wetlands in China. Ecological engineering. 35(10): p. 1367-1378. Retrieved from https://doi.org/10.1016/j.ecoleng.2009.07.007

Zhu, T., et al., (2003) Phosphorus sorption characteristics of a light-weight aggregate. Water Science and Technology. 48(5): p. 93-100. Retrieved from https://doi.org/10.2166/wst.2003.0290 